\title{
Study of Hand Measurements as a Potential Tool for Prediction of Sex and Estimation of Stature in a Sample of Egyptian and Malaysian Youth
}

\author{
Hafsa Salah Mostafa Gheat, Eman Mostafa Soliman, Marwa Mohamed Shahin and Amal Saeed A. F. Hafez ${ }^{1}$ \\ ${ }^{1}$ Department of Forensic Medicine and Clinical Toxicology, Faculty of Medicine, Tanta University, Tanta, Egypt.
}

\begin{abstract}
Background: Identification of the living and the deceased is of great importance in various civil and legal aspects. An individual hand when recovered and brought for examination can give important information about sex, stature and age of the person. Regression equations have been derived in different populations for estimation of stature and they are reliable, accurate and of utmost importance to forensic scientists for medico-legal cases.

Aim of the study: To evaluate hand measurements as a potential tool for determination of sex and estimation of stature in a sample of Egyptian and Malaysian people and to conduct a comparative study between them.

Subjects and methods: The study was conducted on 300 volunteers (200 Egyptians and 100 Malaysians) from both sexes aged above 21 years old and less than 30 years old. Measurement of hand length, breadth and finger lengths of right hand were taken using a sliding caliper (Vernier caliper) beside measurement of the stature using stadiometer.

SPSS was used to compare the recorded measurements between both sexes; logistic regression was conducted to derive equations for prediction of sex from each hand. Multiple regression was performed to estimate stature from hand measurements.

Results: Male measurements of all parameters including hand length, hand breadth, finger lengths of right hand and stature were significantly higher than females in both Egyptian and Malaysian volunteers. There was a moderate to strong positive, statistically significant correlation between stature and the hand length, breadth, and finger lengths of right hand in male and female Egyptian and Malaysian participants. Hand length, hand breadth and thumb length were the best predictors for sex from the right hand, also hand length and index length were the best predictors for stature from the right hand.

Conclusion: Sex and stature can be predicted with reasonable accuracy from hand measurements in Egyptian and Malaysian young adults. Further studies are required to validate the derived equations in a large sample of Egyptians and Malaysians and to test the equations validity in other age groups.
\end{abstract}

Key words $\quad$ Forensic medicine; Forensic anthropology; Stature estimation; Anthropometry; Hand measurements; Egyptians; Malaysians.

\section{Introduction}

Timp dentification of the living and the deceased is of great importance in various civil and legal aspects. The skeleton plays an important role in identification (Khare et al., 2014). Examination of anonymous skeletal remnants is covered by forensic anthropology in medicolegal conditions, which mainly focuses on the assessment of the age, sex, stature and race (Ibrahim et al., 2016).
Sex identification is of great importance since half of population is excluded. As complete skeletons are difficult to be restored, sexual dimorphism should be studied in different bones to assess their accountability to identify sex (Patil and Mody, 2005, Bigonl et al., 2010). Anthropologists and forensic pathologists determine the sex of skeletons by analyzing quantitative and qualitative characters in the bone remains. Generally, the skull and 
os coxae are the most used elements, but they are not always preserved (Barrio et al., 2006).

Hands are the most preferable part of the body for anthropometric measurement (Ibrahim et al., 2016). An individual hand when recovered and brought for examination can give us important information about sex, stature and age of the person (Jeyaseelan et al., 2016). Different proportions and indices have been obtained for sex identification of remnants of human being (Standring et al., 2005).

Prediction of stature occupies relatively a central position both in the anthropological research and in the identification necessitated by the medicolegal experts (Jasuja et al., 2004). There is an established relationship between stature and various body parts like head, trunk, upper and lower extremities (Krishan and Sharma, 2007). Regression equations have been derived in many studies for estimation of stature and they are reliable, accurate and of utmost importance to forensic scientists for medico-legal cases. However, bone characteristics and measurements were found to vary to between different human races (Looker et al., 2009). Therefore, there is a need to specify sexing parameters and stature equations that are specific for each population. Some studies in Egypt have evaluated hand measurements as a tool to identify sex and stature (Aboul-Hagag et al., 2011, Ibrahim et al., 2016). The aim of the present study was to evaluate hand measurements as a potential tool for determination of sex and estimation of stature in a sample of Egyptian and Malaysian people and to conduct a comparative study between them.

\section{Subjects and Methods}

This cross-sectional study was conducted on 300 volunteers (200 Egyptians and 100 Malaysians) during the period from the start of December 2016 till the end of May 2017. The ethical committee approval for this study was obtained from the research ethics committee of faculty of medicine Tanta University. Written informed consent was taken from the volunteers. Confidentiality of the data was maintained by assigning code numbers to the participants that were only known to the investigators.

\section{Inclusion criteria}

Egyptian and Malaysian volunteers - of both sexes - who aged above 21 years old and less than 30 years old, were included in this study.

\section{Exclusion criteria}

Volunteers with any deformity, injury, fracture, amputation or history of any surgical procedures of the hand, limbs, fingers of either hand were excluded from the study.

\section{Data collection}

All participants were subjected to taking of demographic data and history of age, sex, nationality and history of any trauma, bone disease or surgery, Clinical examination to detect any abnormality affecting the stature or upper limbs, $\mathrm{X}$ ray on knee to exclude volunteers with delayed union of epiphysis on upper end tibia, fibula and lower end femur, Measurement of hand length, breadth and finger lengths of both right and left hands and these measurements were taken using a sliding caliper (Vernier caliper) beside measurement of the stature using stadiometer. Stature measurement was done by asking the subject to stand erect on a horizontal resting plane on the stadiometer bare-footed. Palms of hand were turned inwards and fingers were vertically pointing downwards and the head was oriented in eye-ear plane (Frankfurt plane) (fig.1).

The right hand length was measured as the straight distance between the distal crease of wrist joint and the most anterior projecting point, i.e.,the tip of the middle finger (fig.2).

The right hand breadth was measured as the straight distance from the most laterally placed point on the head of $2^{\text {nd }}$ metacarpal bone to the most medially placed point located on the head of $5^{\text {th }}$ metacarpal bone (fig.2). The length of each finger was obtained by measuring the distance between the tip of the finger to the metacarpophalangeal crease (fig.3). The hand and finger measurements were taken using a sliding caliper (Vernier caliper) (fig.4);.and were done as recommended by Weiner and Lourie (1969) and Aboul-Hagag et al. (2011).

\section{Statistical analysis}

Was done using SPSS version 22 for windows. For quantitative data, the Shapiro-Wilk test for normality was performed. For normally distributed data, values were expressed as mean \pm standard deviation and Independent Samples $t$ test was performed for comparison between two groups. For data that were not normally distributed, the median and interquartile range (expressed as 25th75th percentiles) were calculated; Mann-Whitney test, Wilcoxon-signed ranks and Spearman's rank-order correlation were used. For qualitative data, Pearson's Chi square test was used to examine the association between two variables. Logistic regression and multiple regression models were used to predict sex, race and stature from the relevant variables. Significance was adopted at $\mathrm{p}<0.05$ for interpretation of results of tests.

\section{Results}

The current study was conducted on 300 volunteers: 200 Egyptians and 100 Malaysians. Females represented 5 \% of Malaysian participants and $49 \%$ of Egyptian participants.

In Egyptian participants, the stature, both hand lengths and breadths were significantly higher in males than females ( $p$ value <0.05) (Table 1). Also finger measurements of both hands were significantly higher in males than females (p value $<0.05$ ) (Table 1). The mean stature of male and female Egyptian participants was $174.9 \mathrm{~cm}$ and $161.7 \mathrm{~cm}$ respectively. The stature in males was significantly higher than females. The results of Spearman's rank-order correlation showed that there was a strong positive, statistically significant correlation between stature and both hand measurements, in 
Egyptian males (all correlation coefficients were $>0.5$ with $\mathrm{p}<0.05)$.

In Egyptian females the results of Spearman's rank-order correlation showed that there was a strong positive, statistically significant correlation between stature and the right hand length, (all correlation coefficients were $>0.5$ with $\mathrm{p}<0.001$ ). It also showed that there was a moderate positive, statistically significant correlation between stature and the right hand breadth, right middle finger length, right ring finger length, right little finger length. (all correlation coefficients were between 0.3-0.5 with $\mathrm{p}<0.05$ ).

In Malaysian participants, the stature, both right and left hand length and breadth were significantly higher in males than females ( $p$ value $<0.05$; Table 2).

As regard finger measurements, they were significantly higher in males than females in both hands (p value $<0.05$; Table 2 ).

Comparison between right and left hand measurements in the studied participants showed significant differences within each group (Table 3). These differences varied according to the race and sex of participants.

The results of Spearman's rank-order correlation showed that there was a strong positive, statistically significant correlation between stature and the right hand length, right middle finger in Malaysian males and a moderate positive, statistically significant correlation between stature, right hand breadth and the lengths of all right hand fingers (Table 4).

Stepwise forward binary logistic regression analysis that was performed to predict race from the right hand measurements taking sex into consideration. The logistic regression model was statistically significant, $\chi^{2}$ $=$ 68.24, $p<0.001$. The model explained $r \wedge, 0 \%$ (Nagelkerke $R^{2}$ ) of the variance in race and correctly classified $71.7 \%$ of cases. Sensitivity was 39, and specificity was $88.3 \%$ (Table 5 and 6).

The logistic regression equation for prediction of race from right hand measurements is: $\operatorname{logit}(\mathrm{p})=17.788-(0.098 \times$ right hand length $)+(0.205 \times$ right index finger length $)-(0.246 \times$ right little finger length) - (1.665× sex).

Logit(p) can be transformed to $\mathrm{p}$ (probability of

being Malaysian) by the following

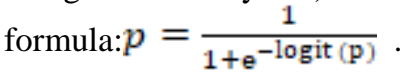

Where sex was coded as 0 for female and 1 for male.

The results of stepwise forward binary logistic regression analysis (Table 5 and 6).that was performed to predict sex from the right hand measurements and race showed a statistically significant model, $\chi^{2}=194.46, p<0.001$. The model explained $64.1 \%$ (Nagelkerke $R^{2}$ ) of the variance in sex and correctly classified $82.8 \%$ of cases. Sensitivity was $85.4 \%$, and specificity was $80.1 \%$.

The logistic regression equation for prediction of sex from right hand measurements is: logit $(p)=39.23-(0.095 \times$ Right hand length $)-(0.168 \mathrm{X}$ Right hand breadth $)-(0.135 \times$ Right thumb length $)$ $(1.752 \times$ Race). Logit(p) can be transformed to $\mathrm{p}$ (probability of being female) by the following formula: $p=\frac{1}{1+e^{-\operatorname{logit}(p)}}$.

Where race was coded as 0 for Egyptians and 1 for Malaysians.

Multiple regression was conducted to predict stature from right hand measurements and both sex and race (Table 5 and 6).). The model was statistically significant to predict stature, $F=162.1, p<0.001$, and explained $68.7 \%$ of the variables. The lengths of the right hand and index finger added significantly to the prediction model. An equation to predict stature was obtained from the regression model as follows:

Predicted height from the right hand $(\mathrm{cm})=$ $95.88+(0.30 \times$ Right hand length $)+(0.29 \times$ Right index length) - (5.74 × sex) - (2.03 X Race).

Where sex was coded as 0 for female and 1 for male; race was coded as 0 for Egyptians and 1 for Malaysians. 
Table (1): Statistical analysis (student $t$ test and Mann-Whitney test) for Comparison of stature and hand measurements between Egyptian male and female participants:

\begin{tabular}{|c|c|c|c|c|c|c|}
\hline \multirow{2}{*}{\multicolumn{2}{|c|}{ Variables }} & \multicolumn{3}{|c|}{ Egyptian participants } & \multicolumn{2}{|c|}{ Test of significance } \\
\hline & & \multirow{2}{*}{$\begin{array}{c}\begin{array}{c}\text { Male } \\
(\mathbf{n}=\mathbf{9 7})\end{array} \\
174.9 \pm 7.2\end{array}$} & \multirow{2}{*}{$\begin{array}{c}\begin{array}{c}\text { Female } \\
(\mathbf{n}=\mathbf{1 0 3})\end{array} \\
161.7 \pm 5.2\end{array}$} & \multirow{2}{*}{$\begin{array}{c}\begin{array}{c}\text { Total } \\
(\mathbf{n}=\mathbf{2 0 0})\end{array} \\
168.2 \pm 9.1\end{array}$} & \multirow{2}{*}{$\begin{array}{c}\text { Test } \\
\text { statistic } \\
\mathrm{t}=14.79\end{array}$} & \multirow{2}{*}{$\frac{\mathbf{P}}{<0.001^{*}}$} \\
\hline Stature (cm) & Mean \pm SD & & & & & \\
\hline $\begin{array}{l}\text { Rt. Hand } \\
\text { length } \\
(\mathrm{mm})\end{array}$ & $\begin{array}{l}\text { Median } \\
\text { IQR } \\
\text { Mean ranks }\end{array}$ & $\begin{array}{c}187.5 \\
182.3-193.9 \\
138.9\end{array}$ & $\begin{array}{c}174.4 \\
168.4-180.1 \\
61.7\end{array}$ & $\begin{array}{c}181.2 \\
173.0-187.7 \\
-\end{array}$ & $\begin{array}{c}U= \\
1078.0\end{array}$ & $<0.001^{*}$ \\
\hline $\begin{array}{l}\text { Rt. Hand } \\
\text { breadth } \\
(\mathrm{mm})\end{array}$ & $\begin{array}{l}\text { Median } \\
\text { IQR } \\
\text { Mean ranks }\end{array}$ & $\begin{array}{c}85.1 \\
80.6-88.9 \\
202.8\end{array}$ & $\begin{array}{c}76.3 \\
73.5-79.9 \\
67.2\end{array}$ & $\begin{array}{c}80.0 \\
75.1-85.9 \\
-\end{array}$ & $\begin{array}{c}U= \\
T 179.0\end{array}$ & $<0.001^{*}$ \\
\hline $\begin{array}{l}\text { Rt. Thumb } \\
\text { length } \\
\text { (mm) }\end{array}$ & $\begin{array}{l}\text { Median } \\
\text { IQR } \\
\text { Mean ranks }\end{array}$ & $\begin{array}{c}65.2 \\
61.6-68.1 \\
131.6\end{array}$ & $\begin{array}{c}59.0 \\
56.6-62.3 \\
68.7\end{array}$ & $\begin{array}{c}61.8 \\
58.3-65.8 \\
-\end{array}$ & 1789.000 & $<0.001^{*}$ \\
\hline $\begin{array}{l}\text { Rt. index } \\
\text { finger length } \\
(\mathrm{mm})\end{array}$ & $\begin{array}{l}\text { Median } \\
\text { IQR } \\
\text { Mean ranks }\end{array}$ & $\begin{array}{c}71.8 \\
68.7-76.3 \\
128.8\end{array}$ & $\begin{array}{c}67.1 \\
64.7-69.5 \\
71.4\end{array}$ & $\begin{array}{c}69.2 \\
66.1-72.9 \\
-\end{array}$ & 2058.500 & $<0.001^{*}$ \\
\hline $\begin{array}{l}\text { Rt. Middle } \\
\text { finger length } \\
(\mathrm{mm})\end{array}$ & $\begin{array}{l}\text { Median } \\
\text { IQR } \\
\text { Mean ranks }\end{array}$ & $\begin{array}{c}81.1 \\
77.2-86.3 \\
133.9\end{array}$ & $\begin{array}{c}74.4 \\
71.5-78.1 \\
66.5\end{array}$ & $\begin{array}{c}77.4 \\
73.8-81.9 \\
-\end{array}$ & 1564.500 & $<0.001 *$ \\
\hline $\begin{array}{l}\text { Rt. Ring } \\
\text { finger length } \\
(\mathrm{mm})\end{array}$ & $\begin{array}{l}\text { Median } \\
\text { IQR } \\
\text { Mean ranks }\end{array}$ & $\begin{array}{c}75.5 \\
71.1-78.4 \\
130.8\end{array}$ & $\begin{array}{c}68.4 \\
66.4-71.0 \\
69.4\end{array}$ & $\begin{array}{c}70.9 \\
67.9-75.5 \\
-\end{array}$ & 1861.500 & $<0.001 *$ \\
\hline $\begin{array}{l}\text { Rt. Little } \\
\text { finger length } \\
(\mathrm{mm})\end{array}$ & $\begin{array}{l}\text { Median } \\
\text { IQR } \\
\text { Mean ranks }\end{array}$ & $\begin{array}{c}61.8 \\
59.2-65.1 \\
135.1\end{array}$ & $\begin{array}{c}56.1 \\
53.8-58.2 \\
65.4\end{array}$ & $\begin{array}{c}58.7 \\
55.4-62.2 \\
-\end{array}$ & 1449.00 & $<0.001^{*}$ \\
\hline
\end{tabular}

n: number; SD: standard deviation; Rt: right; Lt: left; IQR: interquartile range; $t$ : Independent sample T-test; U= Mann-Whitney test; * significant at $p<0.05$.

Table (2): Statistical analysis (student $t$ test and Mann-Whitney test) for Comparison of stature and hand measurements between Malaysian male and female participant:

\begin{tabular}{|c|c|c|c|c|c|c|}
\hline \multirow{2}{*}{\multicolumn{2}{|c|}{ Variables }} & \multicolumn{3}{|c|}{ Malaysian participants } & \multicolumn{2}{|c|}{ Test of significance } \\
\hline & & \multirow{2}{*}{$\begin{array}{c}\begin{array}{c}\text { Male } \\
(\mathbf{n}=\mathbf{5 0})\end{array} \\
169 \pm 6.3\end{array}$} & \multirow{2}{*}{$\begin{array}{c}\begin{array}{c}\text { Female } \\
(\mathbf{n}=\mathbf{5 0})\end{array} \\
158.8 \pm 5.8\end{array}$} & \multirow{2}{*}{$\begin{array}{c}\begin{array}{c}\text { Total } \\
(\mathbf{n}=\mathbf{1 0 0})\end{array} \\
164.0 \pm 8.0\end{array}$} & \multirow{2}{*}{$\begin{array}{c}\text { Test statistic } \\
\mathrm{t}=8.55\end{array}$} & \multirow{2}{*}{$\frac{\mathbf{P}}{<0.001^{*}}$} \\
\hline Stature $(\mathrm{cm})$ & Mean \pm SD & & & & & \\
\hline $\begin{array}{l}\text { Rt. Hand length } \\
(\mathbf{m m})\end{array}$ & $\begin{array}{l}\text { Median } \\
\text { IQR } \\
\text { Mean ranks }\end{array}$ & $\begin{array}{c}184.9 \\
179.2-190.4 \\
71.2 \\
\end{array}$ & $\begin{array}{c}166.4 \\
160.9-171.3 \\
29.8 \\
\end{array}$ & $\begin{array}{c}173.1 \\
165.5-184.9 \\
-\end{array}$ & $\begin{array}{c}U= \\
213.0\end{array}$ & $<0.001^{*}$ \\
\hline $\begin{array}{l}\text { Rt. Hand breadth } \\
(\mathrm{mm})\end{array}$ & $\begin{array}{l}\text { Median } \\
\text { IQR } \\
\text { Mean ranks } \\
\end{array}$ & $\begin{array}{c}82.8 \\
78.9-86.3 \\
72.7 \\
\end{array}$ & $\begin{array}{c}71.7 \\
69.1-74.5 \\
28.3 \\
\end{array}$ & $\begin{array}{c}76.2 \\
71.2-83.0 \\
- \\
\end{array}$ & $\begin{array}{c}\mathrm{U}= \\
142.0\end{array}$ & $<0.001^{*}$ \\
\hline $\begin{array}{l}\text { Rt. Thumb length } \\
\text { (mm) }\end{array}$ & $\begin{array}{l}\text { Median } \\
\text { IQR } \\
\text { Mean ranks }\end{array}$ & $\begin{array}{c}63.7 \\
60.1-71.2 \\
69.3\end{array}$ & $\begin{array}{c}55.4 \\
58.4-75.4 \\
31.6 \\
\end{array}$ & $\begin{array}{c}59.3 \\
54.9-63.9 \\
-\end{array}$ & $\begin{array}{c}\mathrm{U}= \\
306.5\end{array}$ & $<0.001 *$ \\
\hline $\begin{array}{l}\text { Rt. index finger length } \\
(\mathrm{mm})\end{array}$ & $\begin{array}{l}\text { Median } \\
\text { IQR } \\
\text { Mean ranks }\end{array}$ & $\begin{array}{c}71.8 \\
59.3-68.7 \\
69.0\end{array}$ & $\begin{array}{c}64.6 \\
59.4-74.1 \\
31.9 \\
\end{array}$ & $\begin{array}{c}67.6 \\
63.9-73.0 \\
- \\
\end{array}$ & $\begin{array}{c}\mathrm{U}= \\
323.0\end{array}$ & $<0.001^{*}$ \\
\hline $\begin{array}{l}\text { Rt. Middle finger length } \\
\text { (mm) }\end{array}$ & $\begin{array}{l}\text { Median } \\
\text { IQR } \\
\text { Mean ranks }\end{array}$ & $\begin{array}{c}79.9 \\
57.3-69.2 \\
70.0\end{array}$ & $\begin{array}{c}71.3 \\
59.2-74.9 \\
30.9\end{array}$ & $\begin{array}{c}74.2 \\
70.8-74.3 \\
-\end{array}$ & $\begin{array}{c}\mathrm{U}= \\
273.0\end{array}$ & $<0.001^{*}$ \\
\hline $\begin{array}{l}\text { Rt. Ring finger length } \\
(\mathrm{mm})\end{array}$ & $\begin{array}{l}\text { Median } \\
\text { IQR } \\
\text { Mean ranks }\end{array}$ & $\begin{array}{c}74.3 \\
58.8-71.3 \\
69.7\end{array}$ & $\begin{array}{c}65.6 \\
62.1-74.4 \\
31.3 \\
\end{array}$ & $\begin{array}{c}68.7 \\
65.2-74.5 \\
-\end{array}$ & $\begin{array}{c}\mathrm{U}= \\
288.5\end{array}$ & $<0.001^{*}$ \\
\hline $\begin{array}{l}\text { Rt. Little finger length } \\
(\mathrm{mm})\end{array}$ & $\begin{array}{l}\text { Median } \\
\text { IQR } \\
\text { Mean ranks }\end{array}$ & $\begin{array}{c}59.0 \\
57.8-71.5 \\
70.4\end{array}$ & $\begin{array}{c}51.7 \\
58.4-74.6 \\
30.6\end{array}$ & $\begin{array}{c}55.3 \\
51.6-59.5 \\
-\end{array}$ & 257.000 & $<0.001^{*}$ \\
\hline
\end{tabular}

n: number; SD: standard deviation; Rt: right; Lt: left; IQR: interquartile range; $t$ : Independent sample T-test; U= Mann-Whitney test; * significant at $p<0.05$. 
Table (3): Spearmann's rank order correlation between hand measurements and stature in Egyptian and Malaysian participants:

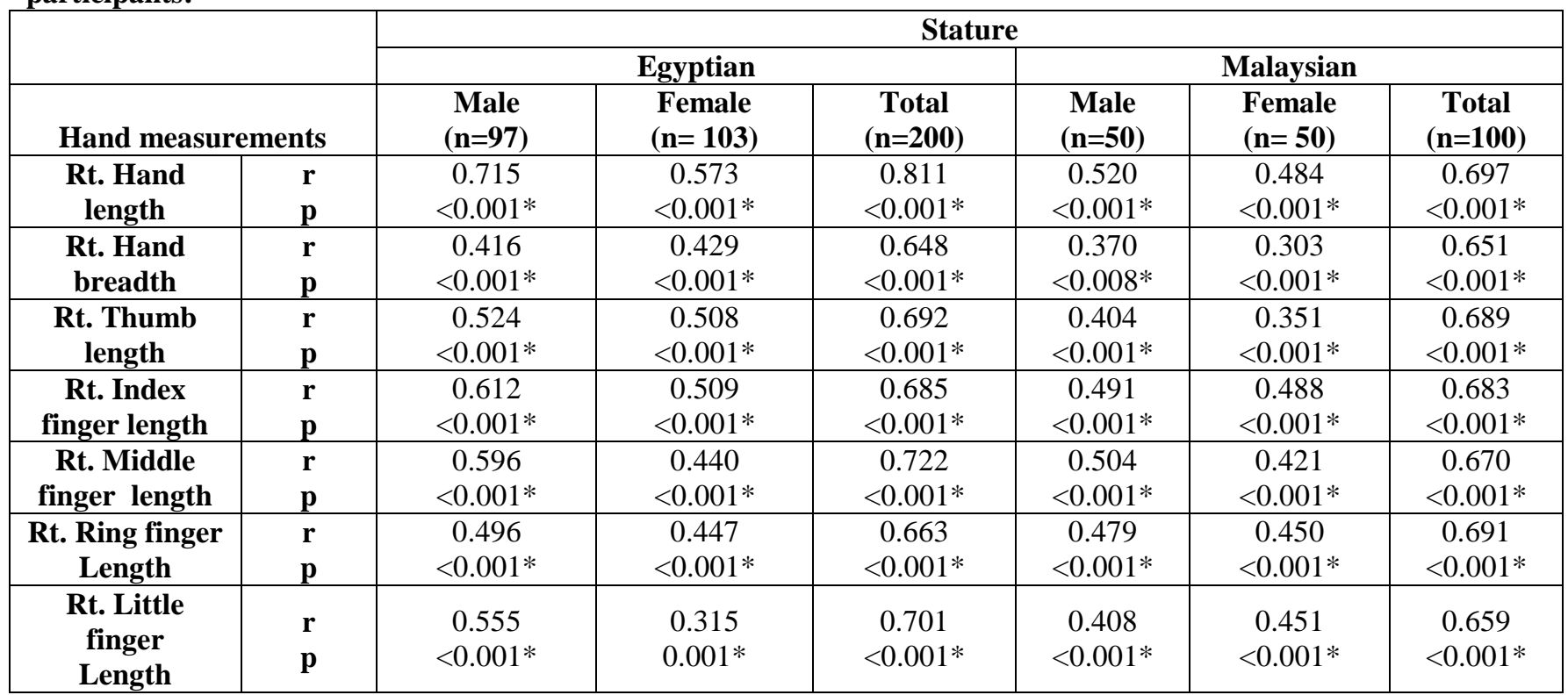

n: number; Rt: right; *significant at p<0.05, r: Spearmann's rank order correlation.

Table (4): Accuracy, sensitivity and specificity of regression models predicting race, sex and stature based on right hand measurements:

\begin{tabular}{|c|c|c|c|c|c|c|}
\hline \multirow{2}{*}{ Model } & \multicolumn{2}{|c|}{ Tests of Model Coefficients } & \multirow{2}{*}{ R Square } & \multirow{2}{*}{ \% accuracy } & Sensitivity & Specificity \\
\cline { 2 - 3 } & Statistic & $\mathbf{p}$ & & & \\
\hline Race & $\mathrm{X}^{2}=68.24$ & $<0.001^{*}$ & 0.285 & $\mathbf{3 9 \%}$ & $\mathbf{8 8 . 3 \%}$ \\
\hline Sex & $\mathrm{X}^{2=} 194.46$ & $<0.001^{*}$ & 0.641 & $82.8 \%$ & $\mathbf{8 5 . 4 \%}$ & $\mathbf{8 0 . 1 \%}$ \\
\hline Stature & $\mathrm{F}=162.1$ & $<0.001^{*}$ & 0.687 & & \\
\hline
\end{tabular}

*significant at $p<0.05 \quad X^{2}$ : chi-square test

Table (5): Variables in regression models predicting race, sex and stature based on right hand measurements:

\begin{tabular}{|c|c|c|c|c|c|}
\hline Model & Variables & $\mathbf{B}$ & $\mathbf{P}$ & Odds ratio & $\begin{array}{c}95 \% \text { CI for odds } \\
\text { ratio }\end{array}$ \\
\hline \multirow{5}{*}{ Race } & Constant & 17.788 & $<0.001^{*}$ & $5.313 \times 10^{7}$ & \\
\hline & Right hand length & -0.098 & $<0.001^{*}$ & 0.149 & $0.066-0.336$ \\
\hline & Right index finger length & 0.205 & $<0.001^{*}$ & 0.906 & $0.858-0.958$ \\
\hline & Right little finger length & -0.246 & $<0.001^{*}$ & 1.227 & 1.111-1.355 \\
\hline & Sex & -1.665 & $<0.001^{*}$ & 0.782 & $0.703-0.870$ \\
\hline \multirow{5}{*}{ Sex } & Constant & 39.23 & $<0.001^{*}$ & $1.085 \times 1017$ & \\
\hline & Right hand length & -0.095 & $<0.001^{*}$ & 0.909 & $0.867-0.954$ \\
\hline & Right hand breadth & -0.168 & $<0.001^{*}$ & 0.845 & $0.787-0.907$ \\
\hline & Right thumb length & -0.135 & $<0.001^{*}$ & 0.874 & $0.807-0.947$ \\
\hline & Race & -1.752 & $<0.001 *$ & 0.173 & $0.075-0.402$ \\
\hline \multirow{5}{*}{ Stature } & Constant & 95.88 & $<0.001 *$ & & 82.89-108.88 \\
\hline & Right hand length & 0.30 & $<0.001 *$ & 0.404 & $0.20-0.41$ \\
\hline & Right index finger length & 0.29 & $0.002^{*}$ & -0.321 & $0.11-0.47$ \\
\hline & Sex & -5.74 & $<0.001^{*}$ & 0.182 & -7.32 to- 4.17 \\
\hline & Race & -2.03 & $0.002 *$ & -0.107 & -3.34 to- -0.73 \\
\hline
\end{tabular}

B: regression coefficient; *significant at $p<0.05$, CI: confidence interval 

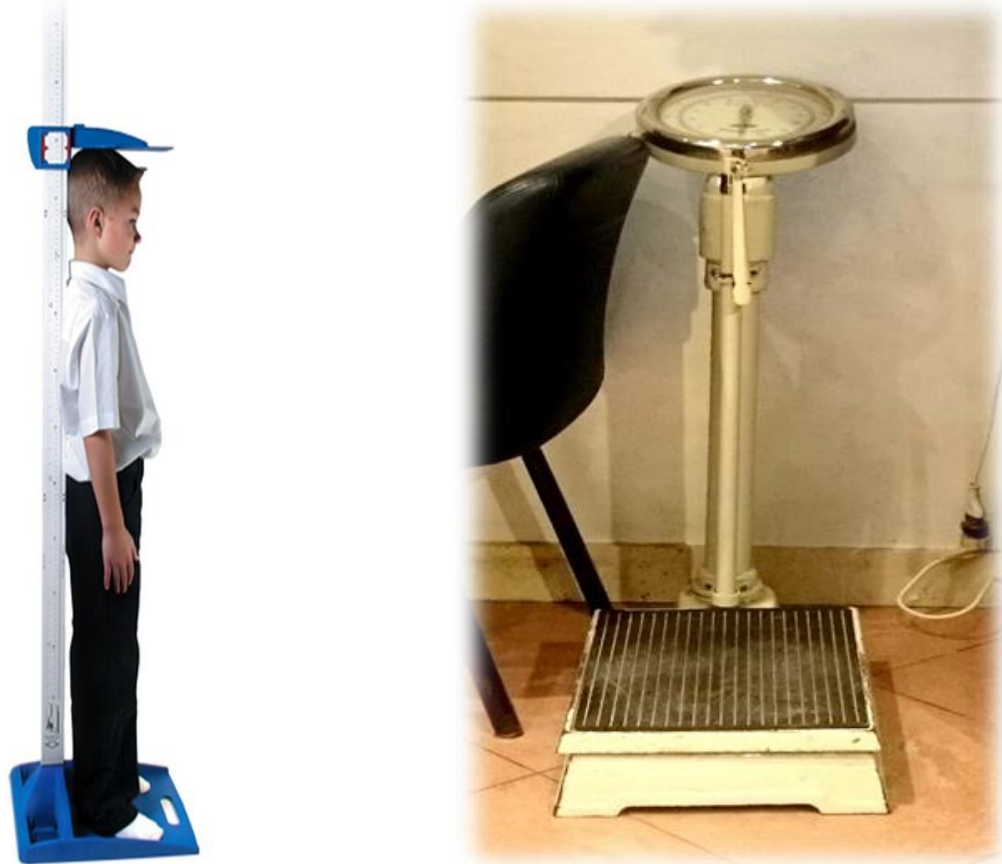

Fig. 1: stadiometer used for stature measurement.

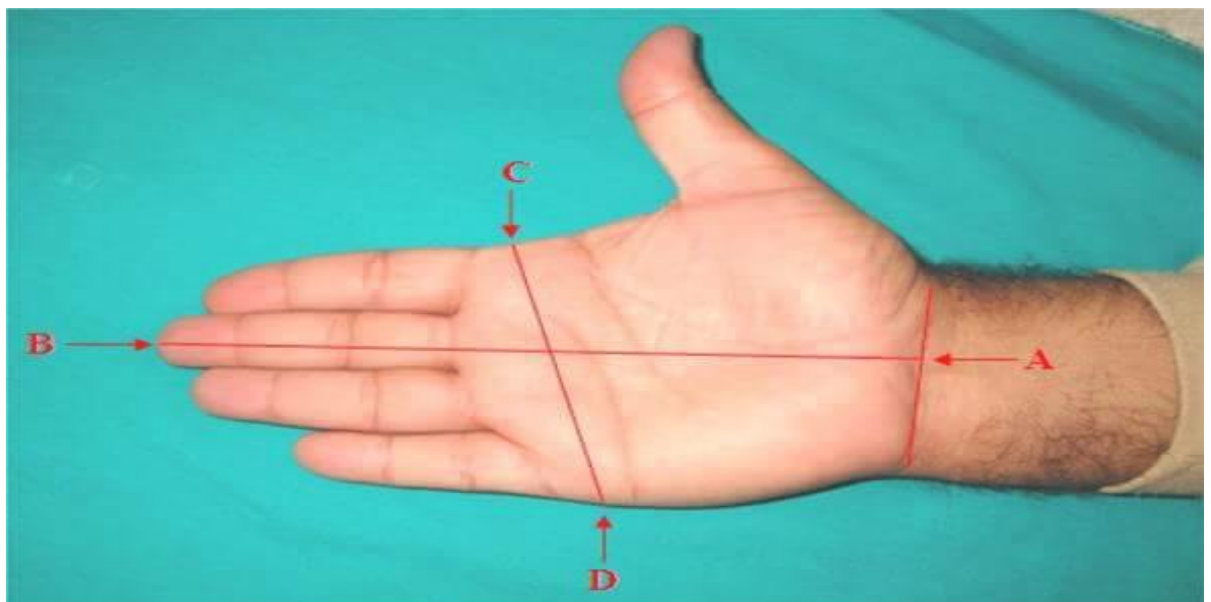

Fig.2: Human hand illustrating the landmarks; hand length (A-B) and hand breadth (C-D) (Aboul-Hagag et al., 2011).

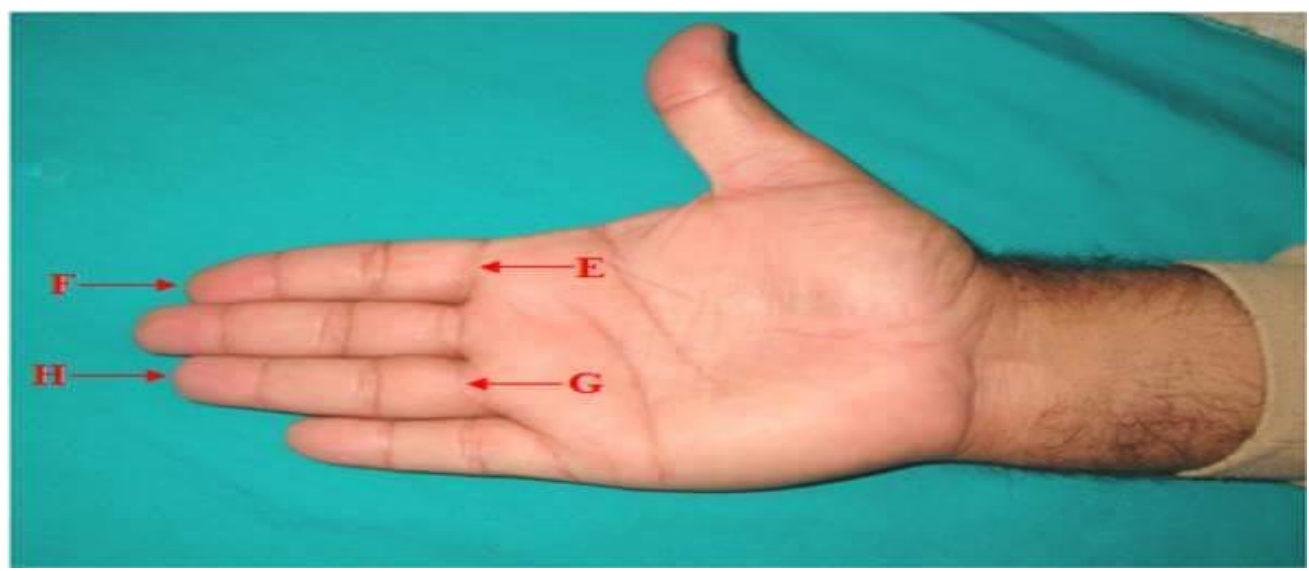

Fig. 3: Human hand illustrating the landmarks of finger lengths (E: F) and (G:H) (Aboul-Hagag et al., 2011). 


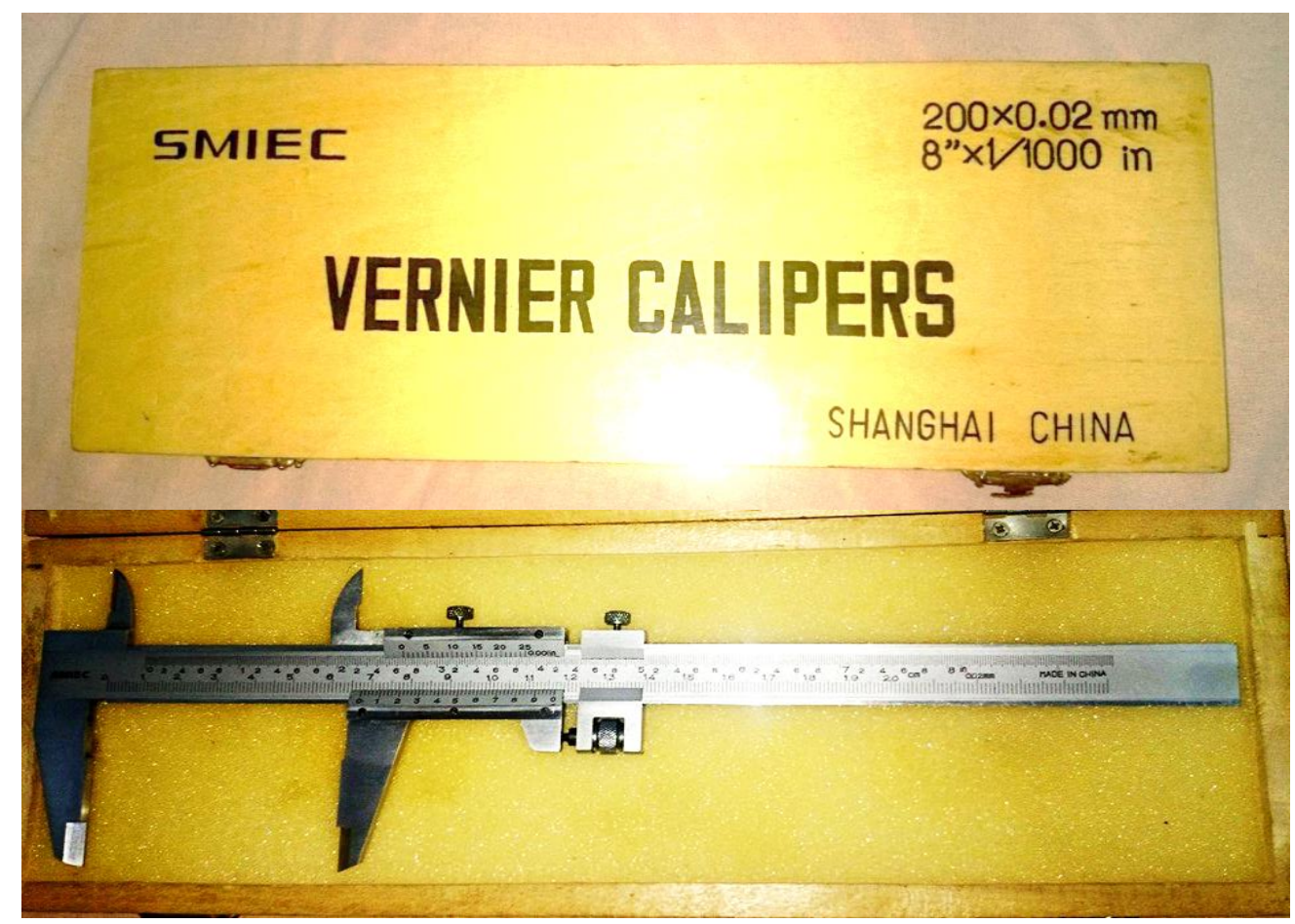

(Fig.4): Vernier Caliper used for taking hand measurements.

\section{Discussion}

This study was carried out on 300 volunteers, 200 Egyptians and 100 Malaysians, to evaluate hand measurements as a potential tool for determination of sex and estimation of stature in a sample of Egyptian and Malaysian people and to conduct a comparative study between them. The study included Egyptian and Malaysian volunteers -of both sexes- who aged above 21 years old and less than 30 years old. This age group was selected as an inclusion criterion for this study in order to be sure of complete development and attaining maximum growth and maturity. Complete union of epiphysis for metacarpals and phalanges in males occur between 14 and 19 years and in females between 13 and 17 years. Therefore, the lower age limit for attaining full maturity in males is 21 years (Jeyaseelan et al., 2016).

In Egyptians, the mean hand lengths in men and women were $187.7 \mathrm{~mm}$ and $174.4 \mathrm{~mm}$, respectively for right hand and $188.7 \mathrm{~mm}$ and $174.4 \mathrm{~mm}$ for left hand. These measurements were slightly nearer to those reported by Okunribido (2000) who stated that the mean value of hand length in general was $185.1 \mathrm{~mm}$ and 177.8 $\mathrm{mm}$ for men and women respectively in Northern states of Nigeria.The Malaysian participants in this study showed even a shorter hand length and mean values were $184.9 \mathrm{~mm}$ and $166.4 \mathrm{~mm}$ for men and women respectively for the right hand. Kanchan and Rastogi (2009) found the mean hand length of both hands to be $179 \mathrm{~mm}$ in Indians. On the contrary, higher mean values of hand length were reported by other studies. Habib and Kamal (2010) stated that the mean right hand length was
$192.9 \mathrm{~mm}$ in Upper Egyptians. Aboul-Hagag et al. (2011) found the mean length of right hand was 194.7 and $194.9 \mathrm{~mm}$ for both men and women respectively.

As regards the hand breadth , differences among populations were found. The mean hand breadth in this study was generally $85.3 \mathrm{~mm}$ for Egyptian men and 76.3 $\mathrm{mm}$ for Egyptian women for the right hand. These results were similar to the mean hand breadth values reported by Aboul-Hagag et al. (2011) in Egyptians (81.3 mm in men and $71.6 \mathrm{~mm}$ in women ); Ibrahim et al. ( 2016b) in Saudis ( $82.3 \mathrm{~mm}$ in men and $74.8 \mathrm{~mm}$ in women ) and by Agnihotri et al. (2006) in Indians ( $84.5 \mathrm{~mm}$ in men and $75 \mathrm{~mm}$ in women ). Higher values for hand breadth were reported by Ahmed (2013) in Sudanese (89 mm) and Lukpata et al. (2015) in Nigerians (86 mm).

The Malaysian participants in this study showed even a shorter hand length and mean values were 184.9 $\mathrm{mm}$ and $166.4 \mathrm{~mm}$ for men and women respectively for the right hand. Kanchan and Rastogi (2009) found that the mean hand length of both hands to be $179 \mathrm{~mm}$ in Indians. On the contrary, higher mean values of hand length were reported by other studies. Habib and Kamal (2010) stated that the mean right hand length was 192.9 $\mathrm{mm}$.

Comparing hand measurements between both sexes in the current study revealed that both hand length, breadth, finger lengths of right hand were significantly higher in the Egyptian and Malaysian men than women of the same race . These results are consistent with previous studies that stated that female hand dimensions 
are smaller than males in different human populations including Egyptians (Abdel-Malek et al., 1990) indians (Jasuja et al., 2004, Agnihotri et al., 2006, Krishan and Sharma, 2007, Kanchan and Rastogi, 2009) and Malaysians (Jeyaseelan et al., 2016).These statistically significant differences may be attributed to the early maturity of girls than boys. Consequently, the boys have two more years of physical growth (Krishan and Sharma, 2007).Therefore, hand measurements can be of potential value for identification of sex.

In the current study, the mean stature of male and female Egyptian participants was $174.9 \mathrm{~cm}$ and $161.7 \mathrm{~cm}$ respectively. These measurements are nearly similar to those reported by previous studies in different populations. Habib and Kamal (2010) studied stature in men and women from upper Egypt and reported mean values of $174.6 \mathrm{~cm}$ and $160 \mathrm{~cm}$ respectively. As regards the Malaysian participants in this study, they have significant shorter stature than the Egyptians $(169.1 \mathrm{~cm}$ in males and $158.8 \mathrm{~cm}$ in females).

In this study, the mean stature of males was significantly higher than females of the same race. These results agree with previous studies that were conducted on Egyptians (Habib and Kamal, 2010, Ahmed, 2013, Sharaf El-Din et al. 2016), Indians (Agnihotri et al., 2008) and Australians (Ishak et al., 2012b). This suggests that developmental processes associated with sexual differentiation play a role in the origin of these sex differences between male and female. Silventoinen et al. (2007) revealed that no two individuals are exactly alike genetically, even identical twins differ in some aspects, and the variability is strongly influenced by genetic and environmental factors and stated that many studies have solidly shown the strong genetic regulation of height and weight from infancy to adulthood. They have also suggested that the genes affecting height and weight are largely the same during the growth period. The Malaysian people, in generally are mostly short in stature, lead an active lifestyle and lives in a hot climate compared to the European, Caucasian, and North American people, who are generally taller, lead a slightly different lifestyle and live in cold climate. The variation in stature in different human populations may be attributed to genetic and environmental factors such as climate and nutrition (Malina et al., 1983, Habib and Kamal, 2010). The environmental factor may have some influence on people's life style, which consequently lead to differences in bone configuration and dimensions in the population. This is the main reason that studies need to be done in a population to represent its people with specific equations for stature estimation (Nor et al., 2013).

Also there was a moderate to strong, positive, significant correlation between stature and the right and left hand lengths, breadths and finger lengths. This result is in concordance with Saxena (1984) in Nigerians. Also, Abdel-Malek et al. (1990) achieved the same results in Egyptians and Jasuja et al., (2004), Krishan and Sharma
(2007), and Rastogi et al. (2008) found the same results in Indians. Thus, hand length is a good parameter for estimating stature

For the malaysian participants, the correlations in male were strong between stature and the right hand length, and right middle finger length, while it was moderate between stature and the right and left hand breadth as well as the right and left hand finger lengths. This is in partial agreement with Tyagi et al. (1999) who studied the subjects from Delhi and found positive correlation between stature and finger lengths but had suggested that index finger was best for the prediction of stature in both males and females. Ahmad et al. (2014) also revealed that the high degree of correlation was found between hand length, hand breadth and stature in South Indian population.These findings indicate the potential value of hand measurements for estimation of stature. As regards race prediction, the results revealed a significant contribution of some of both hand measurements to the prediction of race. An equation was obtained from this model for the right hand as follows:

Prediction of race from the right hand $\operatorname{logit}(\mathrm{p})=$ 17.788- (0.098 $\times$ right hand length $)+(0.205 \times$ right index finger length $)-(0.246 \times$ right little finger length).

As regards sex, the predictive model of right hand showed accuracy of $82.8 \%$ with specificity of 80.1 $\%$ and sensitivity of $85.4 \%$.

The logistic regression equation for prediction of sex derived from the present study was:

Prediction of sex from Right hand measurements $\operatorname{logit}(\mathrm{p})=39.23-(0.095 \times$ Right hand length) - (0.168 $\times$ Right hand breadth $)-(0.135$ Right thumb length) - $(1.752 \times$ Race $)$. Logit(p) can be transformed to $\mathrm{p}$ (probability of being female) by the following formula:

$$
p=\frac{1}{1+\mathrm{e}^{-\operatorname{logit}(\mathrm{p})}} .
$$

The result of the study confirmed that the breadth and lengths of hand and palms can be used for sex determination with $82 \%$ accuracy for right hand and this result is in concordance with the results of the previous study by Ishak et al. (2012a) that showed 94\% and $91.5 \%$ accuracy using hand breadth and lengths of West Australian subjects. However, these findings did not agree with Jee et al. (2015) whose method showed only $54.2 \%$ accuracy in Korean population. Thus, the performance of sex determination using the hand anthropometrics may vary between different nationalities and may have an impact on the accuracy of the methods proposed in the previous studies.

As regards stature prediction, multiple regression analysis was conducted to predict stature from measurements of right hand, sex and race. The model was statistically significant and the study demonstrated a high degree of prediction accuracy. Stature was obtained from the regression model as follows: Predicted height from the right hand $(\mathrm{cm})=95.88+(0.30 \times$ Right hand 
length $)+(0.29 \times$ Right index length $)-(5.74 \times$ sex $)-$ (2.03 $\times$ Race) .

These findings are in concordance with Habib and Kamal (2010) who stated that only the right hand is sufficient for estimation of stature in Egyptian males. Suseelamma et al. (2014) stated that the ring finger is the best to calculate height of the individual in Indian population. Tyagi et al. (1999) studied the subjects from Delhi and found positive correlation between stature and finger lengths and have suggested that index finger was best for the prediction of stature in both males and females. Krishan and Sharma (2007) also observed that a single dimension of hand or foot can estimate stature of an unknown person with a great accuracy in North Indians.

\section{Conclusion and recommendation}

Sex and stature can be predicted with reasonable accuracy from hand measurements in Egyptian and Malaysian young adults. Further studies are required to validate the derived equations in a large sample of Egyptians and Malaysians and to test the equations validity in other age groups using hand measurements on a high scale in identification processes as it is a simple, rapid \& low cost technique and proved to be of high value and can be time saving. Also we recommend doing this study on other parts and governorates across Egypt and compare them with Malaysian population as it was conducted mainly on volunteers from Gharbia governorate.

\section{References}

Abdel-Malek, A. K., Ahmed, A. M., EL Sharkawi, S. A. \& Hamid, N. M. (1990): Prediction of stature from hand measurements. Forensic science international, 46, 181-187.

Aboul-Hagag, K. E., Mohamed, S. A., Hilal, M. A. \& Mohamed, E. A. (2011): Determination of sex from hand dimensions and index/ring finger length ratio in Upper Egyptians. Egyptian Journal of Forensic Sciences, $1,80-86$.

Agnihotri, A., Purwar, B., Jeebun, N. \& Agnihotri, S. (2006): Determination of sex by hand dimensions. The internet journal of forensic science, 1 , 12-24.

Agnihotri, A. K., Agnihotri, S., Jeebun, N. \& Googoolye, K. (2008): Prediction of stature using hand dimensions. Journal of forensic and legal medicine, 15, 479-482.

Ahmad, N., Mohammad, F. \& Farooque, I. (2014): Estimation of height from the long bones of upper limb and hand dimensions in South Indian population. Journal of evidence based medicine and health care, 1, 473-478.

Ahmed, A. A. (2013): Estimation of stature from the upper limb measurements of Sudanese adults. Forensic science international, 228, 178. e1-178. e7.

Barrio, P. A., Trancho, G. J. \& Sanchez, J. A. (2006) Metacarpal sexual determination in a Spanish population. Journal of forensic sciences, 51, 990-995.
Bigonl, L., Veleminska, J. \& Bruzek, J. (2010): Three-dimensional geometric morphometric analysis of cranio-facial sexual dimorphism in a central European sample of known sex. Journal of comparative human biology, 61, 16-32.

Habib, S. R. \& Kamal, N. N. (2010): Stature estimation from hand and phalanges lengths of Egyptians. Journal of forensic and legal medicine, 17, 156-160.

Ibrahim, M. A., Khalifa, A. M., Hagras, A. M. \& Alwakid, N. I. (2016): Sex determination from hand dimensions and index/ring finger length ratio in North Saudi population: Medico-legal view. Egyptian journal of forensic sciences, 6, 435-444.

Ishak, N.-I., Hemy, N. \& Franklin, D. (2012a): Estimation of sex from hand and handprint dimensions in a Western Australian population. Forensic science international, 221, 154. e1-154. e6.

Ishak, N.-I., Hemy, N. \& Franklin, D. (2012b): Estimation of stature from hand and handprint dimensions in a Western Australian population. Forensic science international, 216, 199. e1-199. e7.

Jasuja, O., Singh, G. \& Main, M. (2004): Estimation of stature from hand and phalange length. Journal of indian academy of forensic medicine, 26, 100106.

Jee, S. C., Bahn, S. \& Yun, M. H. (2015): Determination of sex from various hand dimensions of Koreans. Forensic Science International, 257, 521.e1521.e10.

Jeyaseelan, N., Ravindran, P., Pitadeniya, U., Baskaran, V., Mostofa, S., Putraperaman, S. \& ElMugassabi, A. G. A. (2016): Estimation of hand index and sex variations among the university students of Malaysia-An anthropometric study. Journal of humanities and social science, 21, 32-37.

Kanchan, T. \& Rastogi, P. (2009): Sex determination from hand dimensions of North and South Indians. Journal of forensic sciences, 54, 546-550

Khare, P., Shrinivas, B. \& Murty, O. (2014): Manual techniques for bite mark investigation in Indian setup. International journal of medical toxicology \& legal medicine, 16, 1-5

Krishan, K. \& Sharma, A. (2007): Estimation of stature from dimensions of hands and feet in a North Indian population. Journal of forensic and legal medicine, 14, 327-332.

Looker, A. C., Melton, L. J., Harris, T., Borrud, L., Shepherd, J. \& Mcgowan, J. (2009): Age, gender, and race/ethnic differences in total body and subregional bone density. Osteoporosis international, 20, 1141-1149.

Lukpata, P., Ojim, E., Esomonu, U., Okori, S., Egwu, A. \& Ude, R. (2015): Stature Estimation from Hand Dimensions in Bekwarra Ethnic Group of Cross River State, Nigeria. The international journal of science and technoledge, 3, 267.

Malina, R. M., Little, B. B., Stern, M. P., Gaskill, S. P. \& Hazuda, H. P. (1983): Ethnic and social 
class differences in selected anthropometric characteristics of Mexican American and Anglo adults: The San Antonio heart study. Human biology, 55, 867883.

Nor, F. M., Abdullah, N., Mustapa, A.-M., Wen, L. Q., Faisal, N. A. \& Nazari, D. A. A. A. (2013): Estimation of stature by using lower limb dimensions in the Malaysian population. Journal of forensic and legal medicine, 20, 947-952.

Okunribido, O. O. (2000): A survey of hand anthropometry of female rural farm workers in Ibadan, Western Nigeria. Ergonomics, 43, 282-292.

Patil, K. R. \& Mody, R. N. (2005): Determination of sex by discriminant function analysis and stature by regression analysis: a lateral cephalometric study. Forensic science international, 147, 175-180.

Rastogi, P., Nagesh, K. \& Yoganarasimha, K. (2008): Estimation of stature from hand dimensions of north and south Indians. Legal medicine, 10, 185-189.

Saxena, S. (1984): A study of correlations and estimation of stature from hand length, hand breadth and sole length. Anthropologischer anzeiger, 42, 271-276

Sharaf El Din, A. A, ElKholy, S. M \& Yousef, M. I. (2016): Prediction of stature based on upper limb measurements among Egyptian population. European journal of forensic sciences, 3, 1-7.

Silventoinen, K., Bartels, M., Posthuma, D., Estourgie-Van burk, G. F., Willemsen, G., Van beijsterveldt, T. C. \& Boomsma, D. I. (2007): Genetic regulation of growth in height and weight from 3 to 12 years of age: a longitudinal study of Dutch twin children. Twin research and human genetics, 10, 354-363.

Standring, S., Ellis, H., Healy, J., Johnson, D., Williams, A., Collins, P. \& Wigley, C. (2005): Gray's Anatomy: The anatomical basis of clinical practice. American journal of neuroradiology, 26, 2703.

Suseelamma, D., Gayathri. P, Deepthi. S, Chandra Mohan. M, Uday Kumar M \& Amarnath (2014): Study of correlation between stature and length of fingers. Scholars journal of applied medical sciences, 2, 773-784.

Tyagi, A., Kohli, A., Verma, S. \& Aggarwal, B. (1999): Correlation between stature and fingers length. International journal of medical toxicology \& legal medicine, 1, 20-22.

Weiner, J. S. \& Lourie, J. A. (1969): Human Biology, A Guide to Field Methods. Oxford, London: Blackwell scientific publications, 32-3.

\section{الملخص العربي}

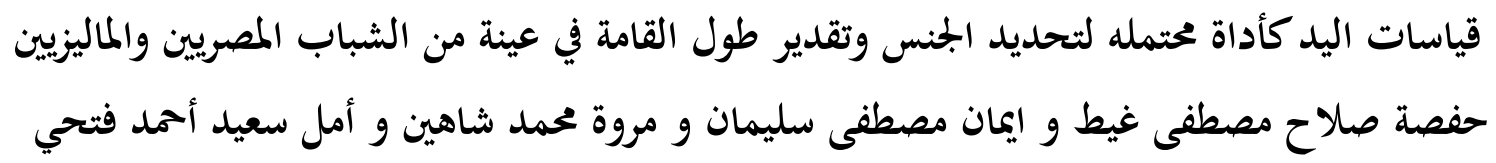

$$
\begin{aligned}
& \text { ان استعراف الاحياء والاموات له اهمية كبيرة في الجوانب المدنيه والقانونية المختلفة. يمكن ان تعطينا اليد الواحدة عند العثور عليها واحضارها للفحص } \\
& \text { معلومات هامة حول الجنس روطول الشخص وعمره ز وقد تم اشتقاق معادلات الانحدار في مجموعات سكانية مختلفة لتقدير القامة وهي موثوقة ودقيقة وذات اهميه } \\
& \text { قصوي لعلماء الطب الشرعي في القضايا الطبية الشرعية. } \\
& \text { الهدف من الدراسة: وكان الهدف من هذه الدراسه هو تقييم قياسات اليد كأداة محتمله لتحديد الجنس وتقدير طول القامة في عينة من الشباب المصريين } \\
& \text { والماليزيين وعقد مقارنة بينهم. }
\end{aligned}
$$

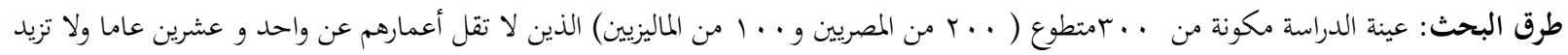

$$
\begin{aligned}
& \text { عن ثلاثين عاما.وقد تم اخذ القياسات وتسجيلها الا وهي : ( قياس طول اليدين اليمني واليسري ,قياس عرض اليدين (اليمني واليسري) وقياس اطوال اصابع اليدين } \\
& \text { اليمني واليسري بالاضافة الي قياس طول القامة للمشاركين في الدراسه ). } \\
& \text { النتائج:وقد كانت قياسات الذكور بمافي ذلك طول اليد وعرضها , وطول اصابع اليد اليمني وطول القامة اعلي بكثير من الاناث في كل من المتطوعين } \\
& \text { المصريين والماليزيين ـ وكان هناك علاقة معتدلة الي قوية, ذات دلالة احصائية بين القامة وطول اليد اليمني وعرضها, وطول اصابع اليد اليمني في المشاركين الذكور } \\
& \text { والاناث المصريين والماليزيين . وكان طول اليد, وعرضها وطول الاجمام افضل قياسات تنبئ بالجنس في اليد اليمني كما كان طول اليد وطول السبابة افضل متنبئ للقامة } \\
& \text { في اليد اليمني. } \\
& \text { الاستنتاج:يمكن التنبئ بالجنس وتقدير طول القامة بدقة مقبولة من قياسات اليد لدي الشباب المصريين والماليزيين وايضا هناك حاجة الي مزيد من } \\
& \text { الدراسات للتحقق من صحة المعادلات المشتقة في عينة كبيرة من المصريين والماليزيين واختبار صحة المعادلات في الفئات العمرية الاخري. } \\
& \text { ا قسم الطب الشرعى والسموم الإكلينيكية كلية الطب - جامعة طنطا - طنطا - مصر. }
\end{aligned}
$$

